\title{
ResearchArticle
}

\section{Biological control of cabbage (Brassica oleracea var. capitata) head rot disease caused by Sclerotinia sclerotiorum}

\author{
S. Malathi
}

\section{SUMMARY}

Head rot disease of cabbage is caused by Sclerotinia sclerotiorum. Efficacy of various biocontrol agents were evaluated for their potential to manage the head rot of cabbage under invitro condition. Among the tested isolates, Trichoderma viride recorded the maximum (85.71\%) inhibition on the mycelial growth of pathogen followed by Pseudomonas fluorescens which recorded 79.15 per cent inhibition on the mycelial growth of Sclerotinia sclerotiorum. Based on the laboratory analysis, effective biocontrol agents were evaluated under glass house and field condition. Among the treatments tested in field condition, combined application of biocontrol agents $(\mathrm{ST}+\mathrm{SA}$ with $(\mathrm{Pf}+\mathrm{Tv})+$ Foliar spray with $\mathrm{Pf})$ significantly recorded maximum (75.26) per cent disease reduction. These biocontrol agents were used an alternative to the chemical for controlling the cabbage head rot disease and enhanced the plant growth parameters and there by increased yield in cabbage.

Key Words : Cabbage, Head rot, Sclerotinia sclerotiorum, Biocontrol agents, Trichoderma viride, Pseudomonas fluorescens

How to cite this article : Malathi, S. (2019). Biological control of cabbage (Brassica oleracea var. capitata) head rot disease caused by Sclerotinia sclerotiorum. Internat. J. Plant Sci., 14 (2): 57-61, DOI: 10.15740/HAS/IJPS/14.2/57-61, Copyright@ 2019: Hind AgriHorticultural Society.

Article chronicle : Received : 21.03.2019; Revised : 01.06.2019; Accepted : 11.06.2019 